\title{
In vitro effect of molluscan hemocyanins on CAL-29 and T-24 bladder cancer cell lines
}

\author{
OLGA BOYANOVA $^{1}$, PAVLINA DOLASHKA ${ }^{2}$, DRAGA TONCHEVA ${ }^{1}$, \\ HANS-GEORG RAMMENSEE ${ }^{3}$ and STEFAN STEVANOVIĆ 3 \\ ${ }^{1}$ Department of Medical Genetics, Medical University of Sofia, Sofia 1431; \\ ${ }^{2}$ Institute of Organic Chemistry with Centre of Phytochemistry, Bulgarian Academy of Sciences, Sofia 1113, Bulgaria; \\ ${ }^{3}$ Institute for Cell Biology, Department of Immunology, University of Tübingen, D-72076 Tübingen, Germany
}

Received July 22, 2012; Accepted September 7, 2012

DOI: $10.3892 /$ br. 2012.46

\begin{abstract}
The aim of this study was to investigate the antitumor effects of molluscan hemocyanins (Hcs) isolated from the marine snail Rapana venosa $(\mathrm{RvH})$ and the garden snail Helix lucorum $(\mathrm{HlH})$ on human bladder cancer cell lines. The antitumor effect of the native molecules of the above-mentioned Hcs and their subunits were examined in comparison to keyhole limpet hemocyanin (KLH), which is the most thoroughly studied Hc. The experiments were conducted using 2 human bladder cancer cell lines: CAL-29 and T-24. Doxorubicin hydrochloride (DOX) and mitomycin-C (MIT-C), which are routinely used in clinical practice to treat bladder cancer, were used for comparison. The viability of the 2 bladder cancer cell lines, used at a concentration of 20,000 cells/well, was measured by WST-1 assay at 24, 48 and $72 \mathrm{~h}$ after treatment with the above-mentioned Hcs and their isoforms at a concentration ranging from 0.8 to $500 \mu \mathrm{g} / \mathrm{ml}$. A direct growth inhibitory effect on the tumor cells was observed mainly after treatment with the native molecule of $\mathrm{HlH}$ and the structural subunit, $\mathrm{RvH} 1$, at a concentration of $500 \mu \mathrm{g} / \mathrm{ml}$. The native molecule of $\mathrm{RvH}$ exhibited an efficacy similar to that of KLH. However, the observed growth inhibitory effect of $\mathrm{HlH}$ was superior to that observed for $\mathrm{KLH}$ and $\mathrm{RvH}$, when used at the same concentration. These findings demonstrate the antitumor effect of other Hcs, apart from KLH. Our data suggest that the native molecule of $\mathrm{HlH}$ and the subunit, $\mathrm{RvH} 1$, are alternative candidates for the treatment of human superficial bladder cancer.
\end{abstract}

\section{Introduction}

Cancer of the bladder is one of the most common types of cancer, while urothelial cancer is the most common histo-

Correspondence to: Professor Pavlina Dolashka, Institute of Organic Chemistry with Centre of Phytochemistry, Bulgarian Academy of Sciences, G. Bonchev 9, Sofia 1113, Bulgaria E-mail: pda54@abv.bg

Key words: hemocyanin, bladder cancer, cell line, therapy logical type of transitional cell carcinoma (TCC), accounting for approximately $90 \%$ of cases and it has a poor prognosis (1).

According to the guidelines on bladder cancer, the treatment options are: surgery, radiation treatment, chemotherapy and immunotherapy, depending on the staging and histological type (2). One of the therapeutic approaches with promising results in clinical trials is the non-specific immunostimulant, keyhole limpet hemocyanin (KLH) Megathura crenulata (3). Hemocyanins (Hcs) are copper-containing respiratory proteins found in arthropods and mollusks $(4,5)$. Due to their high molecular weight, structural heterogeneity and xenogeneic nature, they are known as some of the strongest antigens. The mechanism of action is immune response activation due to the presence of cross-reacting epitopes, such as the Thomson-Friederich antigen [Gal(b1-3) $N$-acetyl epitope] cross-reactive with an equivalent epitope on the bladder tumor cell surface (6) and a carbohydrate epitope on the surface of Schistosoma mansoni larval schistosomes (7). In vivo it induces a protective antibody production against this carbohydrate sequence along with a cytotoxic T-cell response. Subsequent to KLH immunization, patients generate IgG antibodies against $\mathrm{KLH}$ (8). Apart from KLH, the antitumor activities of other Hcs have also been observed. A previous study on the therapeutic properties of Hcs, isolated from the garden snail Helix lucorum $(\mathrm{HlH})$ and the marine snail Rapana venosa $(\mathrm{RvH})$, has shown their activity against Guerin ascites tumor (9).

We hypothesized that $\mathrm{HlH}$ and $\mathrm{RvH}$ may also have a therapeutic effect on bladder cancer. Therefore, the effect of these Hcs on CAL-29 and T-24 bladder cancer cell lines was examined in vitro, in comparison with $\mathrm{KLH}$, doxorubicin hydrochloride (DOX) and mitomycin-C (MIT-C) (used for bladder cancer chemotherapy).

\section{Materials and methods}

Materials and assays. Two bladder cancer cell lines were used in this study: T-24 (TCC, grade III) and CAL-29 (grade IV, stage T2) obtained from the Interfaculty Institute for Cell Biology, Department of Immunology, University of Tübingen, Tübingen, Germany.

The antibiotics, MIT-C and DOX, KLH and Bradford reagent were purchased from Sigma-Aldrich Chemie Gmbh 
(Eschenstrasse, Germany). The WST-1 cell proliferation assay kit was purchased from Roche Diagnostics Deutschland GmbH (Mannheim, Germany), while the Limulus amebocyte lisate (LAL) assay from (Lonza Verviers Sprl, Verviers, Belgium).

Cell culture. The CAL-29 and T-24 cells were cultured as a monolayer in Dulbecco's modified Eagle medium (DMEM, Lonza) supplemented with $10 \%$ fetal calf serum (FCS) and $1 \%$ penicillin-streptomycin $(\mathrm{P} / \mathrm{S})$ (Gibco Invitrogen $\mathrm{GmbH}$, Karlsruhe, Germany) at $37^{\circ} \mathrm{C}$ in a humidified atmosphere with $5 \% \mathrm{CO}_{2}$ until $80 \%$ confluent. Cells were harvested using trypsin/EDTA (Lonza) and counted using a hemocytometer.

Test substance preparation. In the current experiments whole molecules of $\mathrm{HlH}$ and $\mathrm{RvH}$ and 2 structural subunits, RvH1 and RvHI2, were used. Hcs were isolated from the hemolymph of the garden snail $\mathrm{HlH}$ and the marine snail $\mathrm{RvH}$ as described by Dolashka et al (10) and Velkova et al (11). The 2 structural subunits, $\mathrm{RvH} 1$ and $\mathrm{RvH} 2$, were purified after dissociation of the $\mathrm{RvH}$.

The tested substances were filtered using a bacterial filter with a pore size of $0,2 \mu \mathrm{m}$ (Corning ${ }^{\circledR}$ Incorporated Life Sciences, St. Lowell, MA, USA) under sterile conditions. The concentration of the Hc solutions was determined spectrophotometricaly with Bradford reagent. KLH was used for standard curve preparation, $(\mathrm{C}=5,1 \mathrm{mg} / \mathrm{ml}$; Sigma-Aldrich). Optical density (OD) was read on an ELISA reader (SpectraMax 340), $\lambda=595 \mathrm{~nm}$.

In vitro cytotoxicity assay. Cell viability was determined using a standard WST-1 cell proliferation assay. Briefly, the cell lines mentioned above were seeded in 96-well plates (20,000 cells/well). Different concentrations of Hcs ranging from 0.8 to $500 \mu \mathrm{g} / \mathrm{ml}$ were added to the solution after $12-18 \mathrm{~h}$. KLH (Sigma-Aldrich) was used as the positive control at the same concentration as Hcs, while DOX and MIT-C were used at concentrations of $10 \mu \mathrm{g} / \mathrm{ml}$ and $1 \mu \mathrm{M}$, respectively. Medium alone (cells without treatment) was used as the negative control. After incubation for 24, 48 and 72 h, $20 \mu 1$ ready-to-use WST-1 reagent was added to each well and cultured for another $2 \mathrm{~h}$ and the cell viability was determined.

LAL assay. The working procedures were completed under sterile conditions, with pyrogen-free material and the solutions that came into contact with the cells were assayed at $<200 \mathrm{EU} / \mathrm{ml}$ endotoxin using the LAL test.

Statistical analysis. The data are presented as the means with standard deviation (SD). Significance testing was performed using one-way analysis of variance (ANOVA), followed by Bonferroni's post-hoc test. $\mathrm{P}<0.05$ was considered to indicate a statistically significant difference (shown as ${ }^{*} \mathrm{P}<0.05,{ }^{* *} \mathrm{P}<0.01$ and ${ }^{* * *} \mathrm{P}<0.001$ in the figures). The experiments were performed in triplicate and at least 3 times. Most of the experiments were performed 5 times.

\section{Results}

Based on the published information regarding the antitumor effect of Hcs, the antitumor properties of 2 molluscan Hcs extracted from the Bulgarian species, $\mathrm{RvH}$ and $\mathrm{HlH}$, were examined in comparison with KLH. The structure of $\mathrm{HIH}$ and $\mathrm{RvH}$ has been studied thoroughly and their organization was found to differ markedly from the structure of KLH. RvH, HlH and KLH are composed of several oligosaccharide residues exhibiting various tertiary constitutions. In $\mathrm{RvH}$ and KLH 2 structural subunits have been identified, whereas 3 isoforms have been isolated from $\mathrm{HlH}$.

To date, many different protocols have been used to study the antitumor effect of potential pharmacological substances on cancer cell lines $(12,13)$. Two main steps were applied to analyze the antitumor properties of KLH, HlH and $\mathrm{RvH}$ Hcs and their isoforms. The first step was to determine the appropriate (working) concentration of $\mathrm{Hcs}$. $\mathrm{RvH}$ and $\mathrm{HlH}$ were then tested for their effectiveness as antitumor agents on the 2 bladder cancer cell lines. The second step may help us to determine whether Hcs and their isoforms have the potential to be used as an alternative treatment for TCC.

Determination of the appropriate concentrations of Hcs. To determine the working concentration of the Hcs $(\mathrm{KLH}$, $\mathrm{RvH}$ and $\mathrm{HlH}$ and the isoforms, $\mathrm{RvH} 1$ and $\mathrm{RvH} 2) 5$ different concentrations were used: 500, 100, 20, 4 and $0.8 \mu \mathrm{g} / \mathrm{ml}$. Each substance was added to the medium of the bladder cancer cell lines, CAL-29 and T-24. Cell viability was analyzed using a standard WST-1 cell proliferation assay after 24,48 and $72 \mathrm{~h}$ of incubation. The obtained results were compared with the positive control KLH $(500,100,20,4$ and $0.8 \mu \mathrm{g} / \mathrm{ml})$, DOX $(10 \mu \mathrm{g} /$ $\mathrm{ml})$ and MIT-C $(1 \mu \mathrm{M})$ and the negative control cells in medium without treatment. The effect of the tested substances $(\mathrm{HlH}$, $\mathrm{RvH}, \mathrm{RvH} 1$ and $\mathrm{RvH} 2$ ) at 24 and $48 \mathrm{~h}$ was more profound on the CAL-29compared to the T-24 cell line. The greatest cytotoxic effect was observed at a concentration of $500 \mu \mathrm{g} / \mathrm{ml}$ of Hcs; therefore, it was chosen as a working concentration to be used in further experiments. Given the higher effect observed subsequent to the incubation of CAL-29 cells with a lower concentration of $\mathrm{RvH}(100 \mu \mathrm{g} / \mathrm{ml})$, additional experiments were conducted. The effectiveness of the Hcs was compared simultaneously at the concentrations of 100 and $500 \mu \mathrm{g} / \mathrm{ml}$ in both cell lines in order to determine the suitable concentration. As shown in Fig. 1, Hcs at a concentration equal to $500 \mu \mathrm{g} / \mathrm{ml}$ exhibited a greater growth inhibitory effect. This concentration was determined as the working concentration and was used in subsequent experiments to further determine the concentration of Hcs with the best killing effect on the CAL-29 and T-24 bladder cancer cell lines.

Determination of the test Hc with the best cytotoxic effect. The direct in vitro effect of the tested Hcs on the CAL-29 and T-24 bladder cancer cell lines was evaluated in a number of experiments lasting for 24, 48 and $72 \mathrm{~h}$. The Hc concentration used in each experiment was the determined working concentration mentioned above $(500 \mu \mathrm{g} / \mathrm{ml})$.

The effects of native Hc molecules of KLH, molluscan RvH and $\mathrm{HlH}$ and 2 structural subunits, $\mathrm{RvH} 1$ and $\mathrm{RvH} 2$, on the CAL-29 bladder cancer cell line are presented in Fig. 2. The viability measured at 24,48 and $72 \mathrm{~h}$ subsequent to the incubation with the native molecule of KLH was 111.58, 98.14 and $85.23 \%$, respectively. At the same time-points, the cell viability of CAL-29 cells measured subsequent to RvH treatment was 


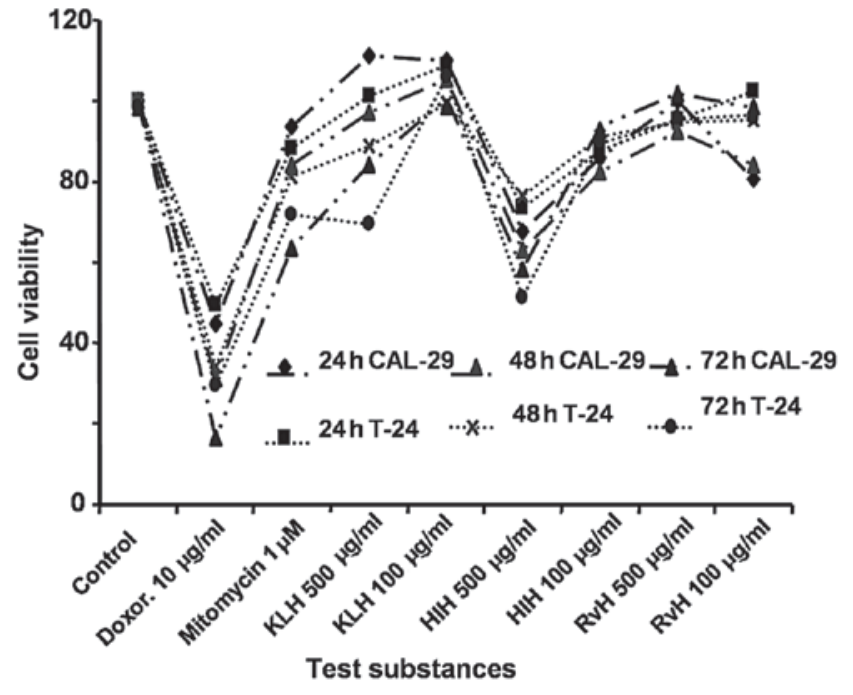

Figure 1. Cell lines viability after 24,48 and $72 \mathrm{~h}$ of incubation with Rapana venosa $(\mathrm{RvH})$, Helix lucorum $(\mathrm{HlH})$ and keyhole limpet hemocyanin $(\mathrm{KLH})$ is shown. The best growth inhibitory effect was detected at the concentration of $500 \mu \mathrm{g} / \mathrm{ml}$.

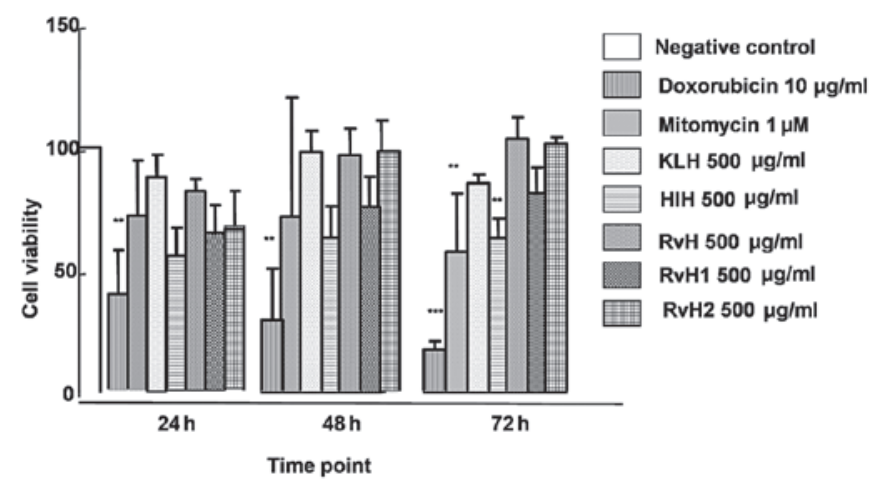

Figure 2. Effect on the human tumor cell line, CAL-29, after 24, 48 and $72 \mathrm{~h}$ of incubation with the native molecule of Rapana venosa $(\mathrm{RvH})$ and Helix lucorum $(\mathrm{HlH})$, and the structural subunits, $\mathrm{RvH} 1$ and $\mathrm{RvH} 2$, at a concentration of $500 \mu \mathrm{g} / \mathrm{ml}$ are shown. The negative and positive controls used were doxorubicin hydrochloride and mitomycin-C (MIT-C), and keyhole limpet hemocyanin $(\mathrm{KLH})$, respectively. ${ }^{* *} \mathrm{P}<0.01,{ }^{* * *} \mathrm{P}<0.001$.

$103.64,96.81$ and $103.23 \%$, respectively. The lowest viability achieved with $\mathrm{HlH}$ was $69.99,63.06$ and $62.73 \%$, respectively. As shown in Fig. 2 only HlH of the native Hcs molecules showed a cytotoxic effect above $30 \%(\%$ cytotoxicity $=100 \%$ - \% viability) after $24 \mathrm{~h}$ of incubation. A slight inhibitory effect was observed after $24 \mathrm{~h}$ of treatment of the CAL-29 cells with the subunits, $\mathrm{RvH} 1$ and $\mathrm{RvH} 2$ (18.01 and $15.53 \%$, respectively). On the contrary, no cytotoxic effects, and stimulation were observed with the native molecule of $\mathrm{RvH}$ and KLH. The cell viability of the CAL-29 cell line after $72 \mathrm{~h}$ of incubation with the native molecule of $\mathrm{HIH}$ was the lowest $(62.73 \%)$ and a growth inhibition of $37.3 \%$ was achieved (at $72 \mathrm{~h}$ ).

Similar effects were observed following the treatment of the T-24 cell line with the native molecules, $\mathrm{RvH}, \mathrm{KLH}, \mathrm{HIH}$, and 2 structural subunits, RvH1 and RvH2. As shown in Fig. 3, cell viability after incubation with the native molecule of KLH at 24,48 , and $72 \mathrm{~h}$ was $107.01,77.03$ and $73.22 \%$, respectively. Cell viability measured subsequent to incubation with $\mathrm{RvH}$ for

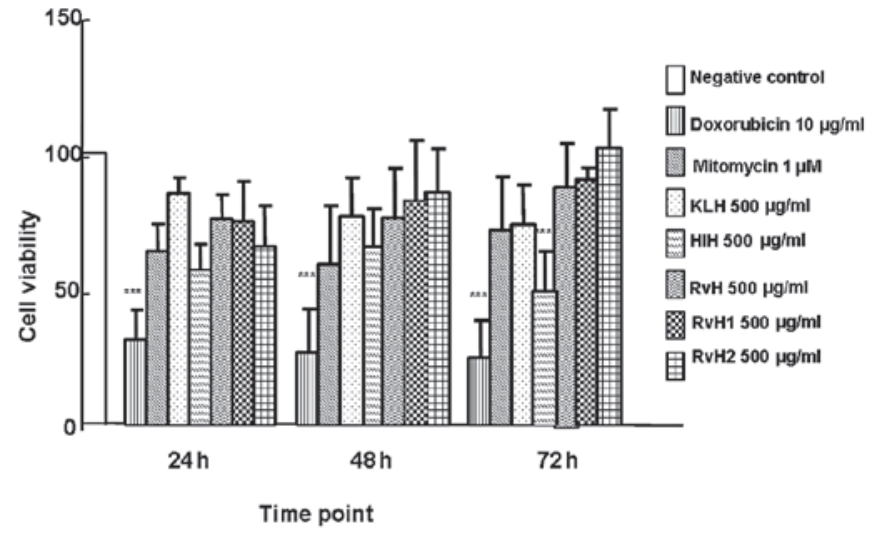

Figure 3. Effect on the human tumor cell line, T-24, after 24, 48 and $72 \mathrm{~h}$ of incubation with the native molecule of Rapana venosa $(\mathrm{RvH})$ and Helix lucorum $(\mathrm{H} \mid \mathrm{H})$, and the structural subunits, $\mathrm{RvH} 1$ and $\mathrm{RvH} 2$, at a concentration of $500 \mu \mathrm{g} / \mathrm{ml}$ in the presence of the negative and positive controls [doxorubicin hydrochloride (DOX), mitomycin-C (MIT-C) and keyhole limpet hemocyanin $(\mathrm{KLH})]$. ${ }^{* * *} \mathrm{P}<0.001$.

the same time period was $95.28,76.53$ and $87.52 \%$, respectively. The cell viability of the T-24 cells treated with $\mathrm{HIH}$ was determined at $71.70,65.75$ and $49.34 \%$ at 24,48 and $72 \mathrm{~h}$ respectively. The cell viability of the T-24 cells decreased from $71.7 \%$ after $24 \mathrm{~h}$ of incubation to $49.34 \%$ after $72 \mathrm{~h}$ of $\mathrm{HlH}$ culturing. The highest growth inhibitory effect (cytotoxic effect) among the Hcs was $50.66 \%$, observed at $72 \mathrm{~h}$ of incubation of the T-24 cells with $\mathrm{HlH}$. An extremely low cytotoxic effect was detected after 24 and $48 \mathrm{~h}$ of incubation with $\mathrm{RvH} 2$ (17.61 and 13.98\%). At $72 \mathrm{~h}$, a stimulation with $\mathrm{RvH} 2$ was observed. The opposite tendency was observed subsequent to RvH1 treatment at 24 , 48 and $72 \mathrm{~h}(4.72,16.99$ and $10.51 \%$ cytotoxicity, respectively).

\section{Discussion}

Hcs are high molecular weight substances, with a xenogenic nature, carbohydrate content and a complicated quaternary structure. This explains their strong immunogenicity in mammals as well as their adjuvanticity in vivo. Their structure, biological function and potential usage in medicine have been extensively studied. One of these Hcs is the molluscan, KLH, a highly antigenic respiratory protein $(5,9)$. It has been used in phase II clinical trials as a drug against bladder cancer (14-20). Moreover, a growth inhibitory in vitro effect of KLH against multiple cancer cell lines, including estrogen-dependent (MCF-7) and -independent breast (ZR75-1), pancreatic (PANC-1, MIAPaCa), prostate (DU145) and Barrett's esophageal adenocarcinoma cancer cell lines, has also been reported (14-16).

Recently, the effect of the application of RvH and KLH on antibody-dependent cellular cytotoxicity (ADCC) and mitogen activity of spleen lymphocytes in hamsters with progressing myeloid Graffi tumors was found subsequent to tumor transplantation (18). The antitumor properties of both $\mathrm{RvH}$ and $\mathrm{HlH}$ as well as their immunological potential, combining in vitro and in vivo methods, was also analyzed $(9,19)$. Strong activation of the immune system of tumor-bearing animals following treatment with RvH was demonstrated. Additionally, the immunostimulatant Hcs were found to induce antitumor activity. 
$\mathrm{KLH}, \mathrm{RvH}$ and $\mathrm{HlH}$ and their isoforms differ markedly in their structures. Their antitumor effects on 2 human bladder cancer cell lines, CAL-29 and T-24 were studied, in comparison with products used in clinical practice for chemotherapy, such as DOX and MIT-C.

In the present study, we demonstrate the growth inhibitory effect of Hcs in vitro. This effect was measured in the presence of a negative and 2 positive controls. The growth inhibitory effect at a range of concentrations between 0.8 and $500 \mu \mathrm{g} / \mathrm{ml}$ was shown in a series of experiments with 24,48 and $72 \mathrm{~h}$ of incubation.

The growth inhibitory effect of common $\mathrm{HlH}$ was shown to be superior to that shown by KLH; $80 \%$ cell was observed viability following KLH incubation for $72 \mathrm{~h}$, and approximately $55 \%$ cell viability was observed following incubation with $\mathrm{HIH}$ (for the CAL-29 and T-24 bladder cancer cell lines). The percentage cytotoxicity was calculated according to the cell the viability ( $\%$ cytotoxicity $=100 \%-\%$ viability). The KLH cytotoxicity in our experiments $(20 \%)$ differs from the one reported by Riggs et al (16) (6-43\%). The difference may be due to the differences in the tumor cell lines tested, the cell density per well and the method used for viability detection. Further studies are required to compare the growth inhibitory effect of structural units and functional subunits isolated from $\mathrm{HlH}$, which may possibly have an even more pronounced effect. In the present study, the growth inhibitory effect of structural subunits isolated from $\mathrm{RvH}$ was examined. The effect of the whole molecule of $\mathrm{RvH}$ and the structural subunits ( $\mathrm{RvH} 1$ and $\mathrm{RvH} 2$ ) measured $72 \mathrm{~h}$ after incubation was found to be similar or lower compared that of KLH.

These findings are consistent with findings from our previous studies $(9,11,18)$ on the immuno-adjuvant properties of these Hcs, their derivatives and conjugates. Those studies investigated the cell-mediated immunity in experimental tumor-bearing animals with Guerin and Graffi ascites tumor $(19,20)$. It was suggested that Hcs carbohydrate moieties are associated with the antitumor potential of different Hcs. High-mannose type glycans, as observed in most molluscan Hcs, were also identified in Hcs from RvH, HlH and KLH.

In the present study on molluscan Hcs isolated from the marine snail $\mathrm{RvH}$ and the garden snail $\mathrm{HIH}$ and the CAL-29 and T-24 bladder cancer cell lines, a growth inhibitory effect of the native molecule of $\mathrm{HlH} \mathrm{Hc}$ and $\mathrm{RvH} 1$ subunit in vitro was demonstrated. Moreover, $\mathrm{HlH}$ was much more effective compared to $\mathrm{KLH}$ and $\mathrm{RvH}$ on the human bladder cancer cell lines.

In conclusion, of the Hcs tested only $\mathrm{HlH}$ showed a higher efficacy compared to KLH investigated in clinical studies as a potential therapy for bladder cancer. Therefore $\mathrm{HIH}$ may be considered for further investigation, as an intravesical therapy for bladder cancer.

\section{Acknowledgements}

This study was funded by a research grant of the Bulgarian National Science Fund TK01-496/2009 and the as well as project ДМУ03/48 from Bulgarian National Science Fund. O.B. and P.D. would like to thank Erasmus and the German Academic Exchange Service (DAAD) for financing this study.

\section{References}

1. Kochanek KD, Xu J, Murphy SL, Miniño AM and Kung H: Deaths: preliminary data for 2009. Nat Vital Stat Rep 59: 2011 (Available at: http://www.cdc.gov/nchs/data/nvsr/nvsr59/nvsr59_04.pdf).

2. Palou J: Patient risk profiles: prognostic factors of recurrence and progression. Eur Urology 41: 105-112, 2002.

3. US National Institutes of Health: Keyhole limpet hemocyanin compared with doxorubicin in treating patients with bladder cancer. http://clinicaltrials.gov/ct2/show/NCT00006034. Accessed March 3, 2011.

4. Dolashka-Angelova P, Dolashki A, Savvides SN, Hristova R, Beeumen JV, Voelter W, Devreese B, Weser U, Di Muro P, Salvato B and Stevanović S: Structure of hemocyanin subunit CaeSS2 of the crustacean Mediterranean crab Carcinus aestuarii. J Biochem 138: 303-312, 2005.

5. Wirguin I, L.Suturkova M, Briani C and Latov N: Keyhole limpet hemocyanin contains Gal(beta 1-3)-GalNAc determinants that are cross-reactive with the T antigen. Cancer Immunol Immunother 40: 307-310, 1995.

6. Li Y, Rabello ALT, Simpson AJG and Katz N: The serological differentiation of acute and chronic Schistosoma japonicum infection by ELISA using keyhole limpet haemocyanin as antigen. Trans R Soc Trop Med Hyg 88: 249-251, 1994.

7. Burke GP, Smith KA, Stocking RIG, Ferm M and McIntyre OR: Anti-keyhole limpet hemocyanin antibody in normal unsensitized individuals. J Allergy Clin Immunol 59: 309-313, 1977.

8. Hortobagyi GN, Smith TL, Swenerton KD, Legha SS, Buzdar AU, Blumenschein GR, Gutterman JU and Hersh EM: Prognostic value of prechemotherapy skin tests in patients with metastatic breast carcinoma. Cancer 47: 1369-1376, 1981.

9. Dolashka P, Velkova L, Iliev I, Beck A, Dolashki A, Yossifova L, Toshkova R, Voelter W and Zacharieva S: Antitumor activity of glycosylated molluscan hemocyanins via Guerin ascites tumor. Immunol Investig 40: 130-149, 2011.

10. Dolashka P, Genov N, Pervanova K, Voelter W, Geiger M and Stoeva S: Rapana thomasiana grosse (gastropoda) haemocyanin: spectroscopic studies of the structure in solution and the conformational stability of the native protein and its structural subunits. Biochem J 315: 139-144, 1996.

11. Velkova L, Dimitrov I, Schwarz H, Stevanović S, Voelter W, Salvato B and Dolashka-Angelova P: Structure of hemocyanin from garden snail Helix vulgaris. Comp Biochem Physiol Mol Biol 157: 16-25, 2010.

12. Rudner J, Ruiner C-E, Handrick R, Eibl H-J, Belka C and Jendrossek V: The Akt-inhibitor Erufosine induces apoptotic cell death in prostate cancer cells and increases the short term effects of ionizing radiation. Radiat Oncol 16: 108, 2010.

13. Kamat A and Lamm D: Antitumor activity of common antibiotics against superficial bladder cancer. Urology 63: 457-60, 2004.

14. Lamm DL: Laboratory and clinical experience with keyhole limpet hemocyanin (Immucothel) in superficial bladder sancer. J Urol Urogynäkol: 18-21, 2003.

15. Jurincic-Winkler CD, Metz KA, Beuth $\mathrm{J}$ and Klippel KF: Keyhole limpet hemocyanin for sarcinoma in situ of the bladder: a long-term follow-up study. Eur Urol 37: 45-49, 2000.

16. Riggs DR, Jackson BJ, Vona-Davis L, Nigam A and McFadden DW: In vitro effects of keyhole limpet hemocyanin in breast and pancreatic cancer in regards to cell growth, cytokine production, and apoptosis. Am J of Surg 189: 680-684, 2005.

17. Moltedo B, Faunes F, Haussmann D, De Ioannes P, De Ioannes AE, Puente J and Becker MI: Immunotherapeutic effect of concholepas hemocyanin in the murine bladder cancer model: evidence for conserved antitumor properties among hemocyanins. J Urol 176: 2690-2695, 2006

18. Toshkova R, Ivanova E, Hristova R, Voelter W and Dolashka-Angelova P: Effect of Rapana venosa hemocyanin on antibody-dependent sell sytotoxicicity (ADCC) and mitogen responsibility of lymphocytes from hamsters with progressing myeloid tumors. World J Med Sci 4: 135-142, 2009.

19. Dolashka-Angelova P, Stefanova T, Livaniou E, Velkova L, Klimentzou P, Stevanović S, Salvato B, Neychev H and Voelter W: Immunological potential of Helix vulgaris and Rapana venosa hemocyanins. Immunol Invest 37: 822-840, 2008.

20. Graffi, A: Chloroleukemia of mice. Ann NY Acad. Sci 68: 540-558, 1957.

21. Yakimov, M, Mladenov Z, Konstantinov A and Yanchev I: Transplantable myeloid tumor in hamsters induced by virus of Graffi. General and Comparative Pathology, 6: 24-30, 1979. 